\begin{tabular}{l}
\hline \hline GEOSPORT FOR SOCIETY \\
$\begin{array}{c}\text { GEOSPORT } \\
\text { SOCIETY }\end{array}$ \\
Scientific Journal founded in 2014 under aegis of University of Oradea (Romania), \\
University of Debrecen (Hungary), University of Gdánsk (Poland) \\
ISSN 2393-1353 \\
Edited by Oradea University Press \\
1, University Street, 410087, Oradea, Romania \\
Journal homepage: $h$ ttp://geosport.uoradea.ro/geosport.html
\end{tabular}

\title{
Wildlife tourism as a developing recreational activity option in Hungary's North Great Plain region and Bihar-Bihor Euroregion
}

\author{
József Márton PUCSOK ${ }^{1 *}$, Péter HIDVÉGI ${ }^{2}$, Andrea Puskás LENTÉNÉ ${ }^{3}$, \\ Melinda BÍRÓ 4
}

\author{
1. University of Debrecen, Institute of Sport Sciences, Hungary, e-mail: pucsok.jozsef@sport.unideb.hu \\ 2. University of Debrecen, Institute of Sport Sciences, Hungary, e-mail: hidvegi.peter@sport.unideb.hu \\ 3. University of Debrecen, Institute of Sport Sciences, Hungary, e-mail: lpandrea@sport.unideb.hu \\ 4. University of Debrecen, Institute of Sport Sciences, Hungary, e-mail: biro.melinda@sport.unideb.hu \\ * Corresponding author
}

Citation: Pucsok, J.M., Hidvégi, P., Lenténé, A.P. \& Bíró, M. (2020). Wildlife tourism as a developing recreational activity option in Hungary's North Great Plain region and Bihar-Bihor Euroregion. Geosport for Society, 12(1), 66-71. https://doi.org/10.30892/gss.1207-058

Article history: 05.03.2020; Revised: 25.04.2020; Accepted: 22.05.2020, Available online: 25.05.2020

\begin{abstract}
According to recent statistical data outdoor adventure activities play an important role in today's tourism industry. This growing tendency based on several factors. Primarily there are more and more people seeking for these types of outdoor activities. Young couples tend to establish family in a later age, typically in their thirties. They have more time for active leisure activities such as hiking and nature walking. In addition, they likely to spend a growing amount of money for any unique touristic experience. Nature walks sometimes combined with other nature-based activities such as discovering wildlife in a given area. Not only are the younger, but older generations also opened to outdoor recreational activities and sports too. There are several options for observing wildlife depending on the geographical location; some of them may offer significant physical challenges. Hungary's North Great Plain region is predominantly flat, while the Bihor region in Rumania is a real mountainous terrain. Hortobágy and the Tisza lake areas offer unique opportunities for birdwatching in Europe. Like any other recreational activity, bird watching is proved to be beneficial for both physical and mental health. Wildlife tourism and avitourism represents serious health-recreational and touristic potential. There is a constant need for quality nature-based sevices, especially associated with wildlife tourism.
\end{abstract}

Keywords: wildlife tourism, recreational activity, healthcare industry, Bihar-Bihor Euroregion

\section{Introduction}

According to recent statistical data, outdoor adventure activities play a significant role in today's tourism market. The growing tendency is supported by several different factors. First, the number of people participating in any outdoor 
activities is continually growing. A wide range of people who are actively seeking outdoor activities. It is a tendency that young women give birth to a child at a later age. This is why these couples have more opportunities to spend money on their adventurous trips. Not only are the younger but senior generations also more likely to choose outdoor activities. These people have high expectations which are a driving force to develop higher quality outdoor services (Dunford, 2008). Since 1990 when the Adventure Travel Trade Association (ATTA) was established a thousand members from one-hundred countries have joined. Annual meetings called, Adventure Travel World Summits have gained increasing popularity over the years (ATTA).

\section{Adventure tourism and activities}

Adventure Travel Trade Association (ATTA) defines adventure tourism as an activity, which is characterized by at least two out of three criteria: 1 . physical activity; 2. performed in outdoors; 3. cultural interaction is present (Dunford, 2008). Adventurous, outdoor activities may help to get out of our daily routine, breaking out of our comfort zone. This way one may discover something new, through overcoming his/her barriers. There is a broad definition of such outdoor activities from whitewater rafting to traditional hiking. The North Great Plain Region is geographically flat, without any mountainous region, compared to other parts of Hungary, or especially Romania's Bihor region the available outdoor activities are somewhat limited. Just across the border, Bihor region is a paradise for naturelovers, with abundant trails for hikers, those who like caving, rappelling, via ferrata or rafting, won't be disappointed either (Lăzuran and Ungureanu, 2014; Ilieș et al., 2017; Dehoorne et al., 2019; Olău et al., 2019; Herman et al., 2019).

The geographical characteristics of the North Great Plain region make it ideal for so-called "soft" activities such as Nordic walking, fishing, bird-watching, canoeing, horse-riding might be an option for more of thrill-seekers. „Avitourism, or avian tourism, is travel and tourism that focuses on and highlights local birding opportunities). Avitourism is one of the fastest growing types of environmental tourism or ecotourism" (Mayntz, 2017, p. 2). Avitourism, including bird-watching, is a fast-growing sector of the international tourism market (figure 1).

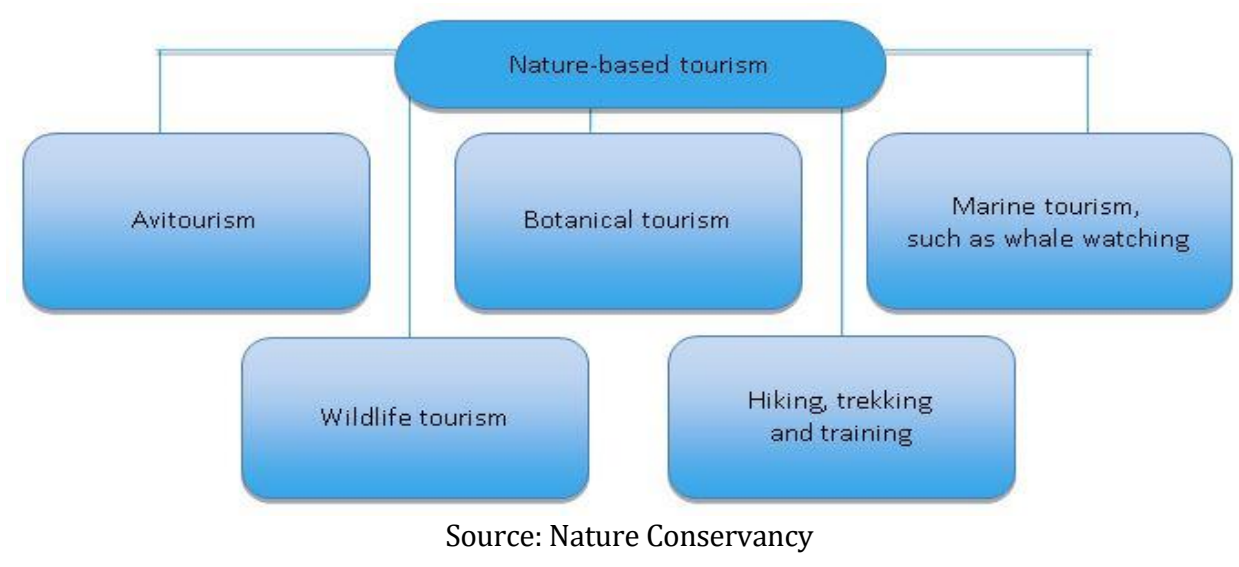


These activities except for horse-riding may be suitable for any generation regardless of age, and physical condition - the other advantage of these activities, that they do not require any significant prior experience.

\section{Major attractions of the Hortobágy, Tisza lake areas}

Hortobágy and Tisza lake areas are one of Eastern Hungary's main touristic attractions, famous for its extraordinary flora and fauna. The Puszta, represented by the Hortobágy National Park, consists of a vast area of natural grasslands, alkaline pastures, meadows, and smaller and larger wetlands and marshes (UNESCO, 2018). Since 1999, Hortobágy Natural Park and Reserve have been selected as a UNESCO World Heritage site, a haven for migrating birds, birdwatching is a popular option, for nature-lovers. A perfect location for hiking trails, one may discover its treasure on a bike or riding a horse. Walking, cycling, horse-riding tours are widely available in this region.

Tisza lake is the second largest lake after Balaton in Hungary with extraordinary natural wonders. Several ecotouristic options are available including bird-watching, canoeing, fishing, cycling, horse-riding, and sailing as well. The eco-center located in Poroszló is the largest sweet water aquarium in Europe (Tisza-tó, 2018).

\section{Flora and fauna of the Bihor region}

The area of Apuseni and Bihor mountains boasts rich flora and fauna, an ideal place for wildlife tourism. The Apuseni Nature Park situated in Rumania in the territory of Alba, Bihor and Cluj counties. This protected area is home to mammals such as the bear (Ursus arctos), the Carpathian elk and the black goat (Rupicapra rupicapra). Rare alpine birds, such as the ural owl (Strix uralensis), the nutcracker (Nucifraga caryocatactes) and the lesser spotted eagle (Aquila pomarina) may be observed in the park. ${ }^{1}$

\section{Birdwatching and mental well-being}

Commonly, walking around in nature rich in vegetation, listening to the birds is a useful tool against stress. Nature walks, hiking, while observing species such as birds may even alleviate anxiety, depression too. More and more people seeking inner peace, for those visiting a natural reserve, observing wildlife may be a possible option. Now we have scientific evidence, that hiking and bird-watching may be beneficial for one's mental health.

Researchers from University of Exeter have recently published a study, involving over 270 participants of varied ages, incomes, and ethnicities. They confirmed that the feathery creatures are a fantastic natural remedy for your mental health. Research conducted by the University of Exeter, the British Trust for Ornithology, and the University of Queensland has demonstrated that people living in greener predominantly suburban areas are significantly less exposed to depression, anxiety, and stress (Cox et al., 2017). In 2016, two researchers also conducted a study 
suggesting bird-watching has a significant beneficial effect on mood, through feelings of relaxation, and interconnection to the natural world (Cox and Gaston, 2016).

According to Kaplan (1995), there is scientific evidence that interactions with nature promote psychological well-being, improved mood state (Barton and Pretty 2010), and reduced stress and anxiety (Grahn and Stigsdotter, 2003; Hartig et al., 2003; Maas et al., 2009). Natural environments, such as natural reserves may provide psychological benefits and also have the potential to be a practical approach to reduce stress and preserve mental health (Hartig et al., 2014; Shanahan et al., 2015).

Several researchers suggest that observing birds may be beneficial for people's mental health status (Curtin, 2009; Brock et al., 2017; Cox and Gaston, 2016, Cobar et al., 2017).

From 2018, medical doctors in the Island of Shetlands may officially prescribe nature walks and birdwatching as a natural treatment for chronic and debilitating illnesses. The physical activity associated with spotting local species such as lapwings, long-tailed ducks, and oystercatchers may help treating stress related illnesses, heart disease and diabetes etc. (Guardian, 2018).

\section{The financial impact of anxiety and mood disorders}

Some scientific evidence, cross-sectional and longitudinal studies suggest, that mood disorders such as depression, may lead to disability or impaired work productivity (Simon, 2003). The overall costs of treating mood disorders may reach an estimated €187.4 billion per year in Europe (Gustavsson et al., 2012; Olesen et al., 2012). After stress, they are one of the most widespread work-related health issues (13.7\% of all reported work-related cases; Eurostat, 2012). This phenomenon may be originated from the increasing gap between people and nature that is resulting from more urbanized, sedentary lifestyles (Soga and Gaston, 2016). Hiking in nature includes activities such as observing wildlife or bird-watching may be one of the solutions to relieve stress and anxiety.

\section{Conclusions}

Wildlife tourism combined with other recreational activities such as hiking; canoeing may not only promote mental health but improve physical fitness too. It may be challenging to estimate the extent of these beneficial effects, researchers such as Brock et al., and Curtin investigated the interaction with nature and everyday wildlife, who emphasized the positive psychological effects. Cox et al., 2017 delivered one of the most comprehensive surveys, including 236 respondents on this topic. They collected data utilizing the short version of the Depression, Anxiety, and Stress Scale (DASS 21) study. Primarily mental, psychological status, socio-demographic, personal data, additionally the amount of physical activity was assessed. We may conclude that, hiking and observing wildlife have a beneficial effect on the individual's overall mental and physical health status, this way the healthcare industry is impacted too.

In the future, we advise to measure the magnitude of physical activity associated with every bird-watching (wildlife observing) trip, in North Great Plain Region, or Bihor region using a self-assessment survey method. Focusing not only the 
mental rather the cardiovascular benefits of observing wildlife (hiking), this may further enhance the popularity of nature-based tourism.

Acknowledgment: This study was supported by the EFOP-3.6.2-16-2017-00003 project which is financed by the European Union and the European Social Fund.

\section{References}

Barton, J., \& Pretty, J. (2010). What is the best dose of nature and green exercise for improving mental health? A multi-study analysis. Environmental science \& technology, 44(10), 3947-3955.

Brock, M., Perino, G., \& Sugden, R. (2017). The warden attitude: An investigation of the value of interaction with everyday wildlife. Environmental and Resource Economics, 67(1), 127-155.

Cobar, A. G. C., Borromeo, M. C. B., Agcaoili, J. K. M., \& Rodil, A. M. T. (2017). Acute effect of birdwatching on mood states of senior high school students in the physical education setting. Ovidius University Annals, Series Physical Education \& Sport/Science, Movement \& Health, 17(1), 18-25.

Cox, D. T., \& Gaston, K. J. (2016). Urban bird feeding: connecting people with nature. PloS one, 11(7).

Cox, D. T., Shanahan, D. F., Hudson, H. L., Plummer, K. E., Siriwardena, G. M., Fuller, R. A., ... \& Gaston, K. J. (2017). Doses of neighborhood nature: the benefits for mental health of living with nature. BioScience, 67(2), 147-155.

Curtin, S. (2009). Wildlife tourism: The intangible, psychological benefits of human-wildlife encounters. Current Issues in Tourism, 12(5-6), 451-474.

Dehoorne, O., Olău, V. M., \& Caciora. T (2019). Tourist Resources Assesement in Pădurea Craiului Mountains. Folia Geographica, 61(2), 163-171.

Dunford, J. (2008). Adventure tourism-Europe. Travel \& Tourism Analyst, (8), 1-47.

Eurostat (2012). The Economy. Pages 141-196 in Schafer G, Cervellin S, Feith M, Fritz M, eds. Europe in Figures: Eurostat Yearbook. European Union Publications Office.

Grahn, P., \& Stigsdotter, U. A. (2003). Landscape planning and stress. Urban forestry \& urban greening, 2(1), 1-18.

Gustavsson, A., Svensson, M., Jacobi, F., Allgulander, C., Alonso, J., Beghi, E., ... \& Gannon, B. (2011). Cost of disorders of the brain in Europe 2010. European neuropsychopharmacology, 21(10), 718-779.

Hartig, T., Evans, G. W., Jamner, L. D., Davis, D. S., \& Gärling, T. (2003). Tracking restoration in natural and urban field settings. Journal of environmental psychology, 23(2), 109-123.

Hartig, T., Mitchell, R., De Vries, S., \& Frumkin, H. (2014). Nature and health. Annual review of public health, 35, 207-228.

Herman, G. V., Varodi, M. O., Grama, V., \& Morar, C. (2019). Geographical Considerations Regarding the Tourist Destination Pădurea Craiului Mountains. Analele Universității din Oradea, Seria Geografie, 29(1), 102-108.

Ilieș, D. C., Baias, S., Buhaș, R., Ilieș, A., Herman, G. V., Gaceu, O., ... \& Măduța, F. (2017). Environmental education in protected areas. Case study from Bihor County, Romania. GeoJournal of Tourism and Geosites, 19(1), 126-132.

Kaplan, S. (1995). The restorative benefits of nature: Toward an integrative framework. Journal of environmental psychology, 15(3), 169-182.

Lăzuran, A., \& Ungureanu, M. (2014). Adventure tourism an insufficiently exploited opportunity in Bihor County, Romania. Analele Universităţii din Oradea, Seria Geografie, 24(1), 44-54.

Maas, J., van Dilen, S. M., Verheij, R. A., \& Groenewegen, P. P. (2009). Social contacts as a possible mechanism behind the relation between green space and health. Health and Place, 15, 586-595.

Mayntz, M. (2017). Avitourism-Birding Travel, https://www.thespruce.com/glossary-definitionavitourism-385168

Olău, V. M., Cristea, D. I., Pop, A. C., \& Gozner, M. (2019). Sport and adventure in the Pădurea Craiului Mountains. Geosport for Society, 11(2), 48-58.

Olesen, J., Gustavsson, A., Svensson, M., Wittchen, H. U., Jönsson, B., CDBE2010 Study Group, \& European Brain Council. (2012). The economic cost of brain disorders in Europe. European journal of neurology, 19(1), 155-162. 
Shanahan, D. F., Lin, B. B., Bush, R., Gaston, K. J., Dean, J. H., Barber, E., \& Fuller, R. A. (2015). Toward improved public health outcomes from urban nature. American journal of public health, 105(3), 470-477.

Simon, G. E. (2003). Social and economic burden of mood disorders. Biological psychiatry, 54(3), 208-215.

Soga, M., \& Gaston, K. J. (2016). Extinction of experience: the loss of human-nature interactions. Frontiers in Ecology and the Environment, 14(2), 94-101.

\section{Web-sites sources:}

Apuseni Nature Park, http://romaniatourism.com/park-nature-apuseni.html, accessed at 10. 10. 2019. Adventure Travel Trade Association, https://adventuretravel.biz, accessed at 10.10. 2019.

Guardian, https://www.theguardian.com/uk-news/2018/oct/05/scottish-gps-nhs-begin-prescribingrambling-birdwatching, accessed at 10.10. 2019.

Tisza-tó, https://www.tisza-to.com, accessed at 10.10.2019.

UNESCO, https://whc.unesco.org/en/list/474, accessed at 10. 10. 2019.

The Nature Conservancy, https://www.nature.org/en-us/explore/animals-we-protect-test/, accessed at 10. 10. 2019. 